of my images are very vague and indefinite that I begin to think it is because they were never expressed. Expression was not a feature in my education, and I think I never was educated. There was no necessity for a strong image in the régime under which I studied, because no expression was asked for. Expression demands a strong image, and cannot be had without it. Expression brings the growing image. I thought I had a fairly strong image of the surface of Mexico until I began to model it. Then I had to go over and over all I had heard and seen for the improvement of my image. I find the strongest images I have ever had were those gained out of school, but I never realized until to-day that the reason is this-that I executed or expressed them. I did not need strong images in order to pass my examinations and get high marks, and that is what I worked for in school. We can do nothing without first imaging. It follows that what we have executed or done has required the strongest images. When I have planned and thought and executed for my household, I have had the strongest images. I had to image when I prepared and served a dinner or directed it. I think I know now one reason why I always disliked history and thoroughly liked any sort of mathematical work. History was merely a memorizing of statements for me. Arithmetic, algebra, and geometry gave me something to work out. The test of the strength of the image is expression. Even the most general form of expression, speech, reveals the weakness of the image.

Discussion: How can one gain strong images?
I cannot tell, but I feel sure that expression is not merely a test of a strong or a weak image; it is also a means of getting strong images. For example, we went to the conservatory to paint the banana tree. I realized when I came away that if I had learned nothing about drawing or painting, I had learned much of the banana tree. The date palm we did not try to draw, but I was much interested in it, having never seen one before. To-day, I cannot recall the form or appearance of it. This shows the relation of expression to the gaining of strong images.

The strong image is also gained by thinking out processes for one's self, by reaching conclusions after a process of reasoning, instead of having the conclusion of others presented first. For example, in our history work I know the images that I hold of the stages and development of primitive man, which I gained from thinking about it myself and discussing it in the class, are much stronger than if I had read these statements and learned them, or if some one had told them to me.

Note: I never was asked to think or give an opinion of my own in my previous school-work. I cannot remember of ever being asked for my own opinion on any subject. When I first heard all of this discussion of strong images I felt discouraged, realizing how weak and vague my images had always been, and I felt that I never could teach with such a stock of attenuated images; but now I think my lack might make me all the more zealous that children should never have so dead a thing thrust upon them in lieu of teaching as I have. My idea of teaching is revolutionized.

\title{
Notes on Plan for the Study and Record of Pupils
}

\section{Francis W. Parker}

The purpose of this plan is, primarily, to enable teachers to study their pupils. The record of teaching and training must be read in the body, mind, and soul of the pupil. Each item in the blank is a standpoint of observation from which qualities of character may be rightly estimated. Experience proves that most teachers, no matter how sound their theories, are dominated by the knowledge and skill ideal; they fix their minds unwittingly, and often unwillingly, upon definite amounts of knowledge, and not upon qualities of character. To change from the old ideal to the new means the breaking up of the inveterate habit of holding knowledge as the aim of teaching, and substituting therefor the new and living way of charac- 


\section{PLAN FOR THE STUDY OF PUPILS}

\begin{tabular}{|c|c|c|c|}
\hline $\begin{array}{l}\text { I. Motive aS } \\
\text { MaNIFESTED IN }\end{array}$ & II. INTELLECT. & III. BoDy. & IV. EXPRESSION. \\
\hline $\begin{array}{l}\text { I. Personal influence } \\
\text { upon the class. } \\
\text { 2. Personal influence } \\
\text { upon the school. } \\
\text { 3. Courtesy and po- } \\
\text { liteness. } \\
\text { 4. Kindness. } \\
\text { 5. Genuineness and } \\
\text { honesty. } \\
\text { 6. Responsibility. } \\
\text { (a) Trustworthi- } \\
\text { ness. } \\
\text { 7. Moral courage. } \\
\text { 8. Respect for the } \\
\text { rights of others. } \\
\text { 9. Helpfulness. } \\
\text { I0. Taste. } \\
\text { I. Cheerfulness. }\end{array}$ & $\begin{array}{l}\text { I. Attention, or Im- } \\
\text { aging. } \\
\text { (a) Correlation } \\
\text { of images. } \\
\text { (b) Observation. } \\
\text { (c) Hearing lan- } \\
\text { guage and } \\
\text { study. } \\
\text { (d) Reading and } \\
\text { study. } \\
\text { (e) Analysis. } \\
\text { (f) Comparison. } \\
\text { (g) Judgment. } \\
\text { (h) Inference. } \\
\text { (i) Casual rela- } \\
\text { tions. } \\
\text { 2. Originality. } \\
\text { (a). Creative } \\
\text { power. } \\
\text { (b) Tact. } \\
\text { 3. Will, as manifest- } \\
\text { ed by persistence } \\
\text { in study. } \\
\text { (a) Effort to im- } \\
\text { prove. } \\
\text { 4. Judgmentinmeas- } \\
\text { uring quantity. } \\
\text { (a) Reason in } \\
\text { applied } \\
\text { mathematics. }\end{array}$ & $\begin{array}{l}\text { 1. Health. } \\
\text { 2. Care of Health. } \\
\text { 3. Cleanliness. } \\
\text { 4. Nutrition. } \\
\text { 5. Habitual Posture. } \\
\text { 6. Senses. } \\
\text { (a) Sight. } \\
\text { (b) Hearing. } \\
\text { 7. Motor Control. } \\
\text { 8. Rhythm. }\end{array}$ & $\begin{array}{l}\text { I. Voice. } \\
\text { 2. Singing. } \\
\text { 3. Speech. (Thought.) (Technique.) } \\
\text { 4. Oral Reading. (Tho.) (Tech.) } \\
\text { 5. Dramatic Power. } \\
\text { 6. Writing. (Tho.) (Tech.) } \\
\text { 7. Laanguage. } \\
\text { 8. Making. } \\
\text { (a) Woodwork. (Tho.) (Tech.) } \\
\text { (b) Textile. (Tho.) (Tech.) } \\
\text { (c) Modeling. (Tho.) (Tech.) } \\
\text { (d) Painting. (Tho.) (Tech.) } \\
\text { (e) Drawing. (Tho.) (Tech.) } \\
\text { 9. Housekeeping. } \\
\text { (a) Cooking. } \\
\text { (b) Cleanliness. } \\
\text { (c) Neatness. } \\
\text { (d) Attention to Details. } \\
\text { (e) Skill. }\end{array}$ \\
\hline \multicolumn{4}{|c|}{ 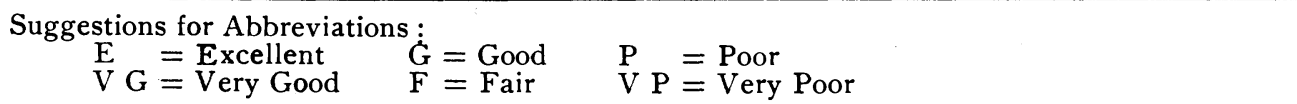 } \\
\hline
\end{tabular}

ter-building. This radical change demands steady and prolonged concentration upon the natures, instincts, tendencies, and characteristics of children, to the end that the one thing needful-character-be developed.

This blank is, then, for the self-criticism of the teacher. The first and last duty of the teacher is to acquire skill and efficiency in the art of arts, teaching. To this purpose every energy should be bent, every thought tend, all study culminate. Within just limits the faults of the pupil are manifest signs of inefficiency on the part of the teacher. Insolence, impertinence, indifference, and inattention are the negative results of ineffective teaching and training. The proof of this assertion is that another teacher may have nearly perfect order with the same pupils.

All the richness and fullness of subjectmatter, all the modes of expression, the strong stimulus and strong incentives of community life, the ever-active instincts of children, the children's craving for work, their hunger for knowledge-all these every teacher has at his service, if he will use them. The teacher has no ground to go over, no definite quantity of knowledge and skill to teach. He has only one thing to do, and that is to present the right conditions for the evolution of the qualities of righteous character. The long pathway that leads up to the art of arts is concentration upon the character of the pupil.

A second use of this blank is mutual aid 
on the part of the teachers in a school in understanding their pupils. Differing judgments of pupils on the part of teachers should lead to a mutual understanding. A difference in opinion may be a difference in the quality of teaching, and it may be a difference in discernment of character.

It is necessary for the principal of a school to have reports on the pupils in the school, in order to make recommendations to parents, and to suggest better means for the growth of pupils. Teachers should mark only those qualities of which they are sure. They should do nothing by guess. If they are not able to mark any one quality here put down, they should make further study of the pupil.

The moral, mental, and physical qualities are grouped opposite each other in the blank, so that the attention of the teacher may be easily called to their relations.

The abbreviations used are simply for economy in reporting. This blank is never to be seen by the pupil, nor even known to him, and there is, therefore, no danger in it of a false stimulus.

Space is left at the bottom of the blank for anything the teacher may wish to write in addition to what the blank calls for.

The blank will be kept year after year, and filed for reference. Special records of pupils may be kept by class and departmental teachers. These will go more into detail than it is possible to do in a report like this.

Finally, this blank is simply tentative. The thought and discussion of all the faculty are to be brought to bear on the devising of a blank that shall be as nearly perfect as possible.

I. Motive: Every pupil, like every other human being, is constantly striving to accomplish something, to reach some end and aim, near or remote; bad or good. The being in action, under the incentive of the end to be realized, constitutes motive. To recognize a pupil's motive in one phase, at least, is to know that pupil. The tact to change a wrong motive to a right one is one of the most valuable qualities in the art of teaching; for to induce and cultivate right motives comprehends the whole art of teaching. For lack of something better to do, pupils often try to tease the teacher (a biological experiment). The cure is at hand; decline to be vexed. Pupils like to "show off," to make their mates laugh, etc. Tact in a teacher is to discern immediately the pupil's motive and to change it to that which is good and wholesome.

INFLUENCE UPON The Class. That which above all things tests a pupil's character is his influence upon his mates. His example in work, play, self-control, order, is the main thing to be cultivated. Sympathy, helpfulness, kindness, thoughtfulness for others, are the signs of good influence. As citizenship is the ideal, personal influence is the test of citizenship.

Courtesy and Politeness. The intrinsic quality of order in the school is true, soulfelt courtesy and politeness. Respect for the rights of others, reverence for authority; sympathy for all, and especially for the weak and unfortunate; kindness, interest in the welfare of the community, are the essential qualities of character, all of which spring from courtesy and politeness. A cheery "Good morning," a hearty handshake, a smiling face, all add much to the day's work.

Genuineness. Genuineness is the true, honest, independent manifestation of self in thought and action. Its opposite, hypocrisy, is the covering up, the suppression of self, in order to conform to the ideas of others, especially to those in authority. The motive for such conduct is love for approbation, the gaining of favors, high marks, and they desire "to show off." 
Lack of genuineness is generally caused by a weakness of will-power.

Hypocrisy is a very common product of the school, and is too often cultivated by teachers. Teachers may like to have their opinions unquestioned, their statements taken without discussion. They often rely upon the words of the text, hold them as infallible, and insist upon their literal acceptation. The innocent pupils soon learn to comply, conform at least outwardly, and never have, much less utter, an original thought. Moral courage is the root of genuineness.

Genuineness is by no means a synonym for goodness. It enables the teachers, however, to understand their pupils, without which very little true progress can be made. Shrewdness, sharpness, acuteness, may be easily developed, but genuine honesty is quite different. It stands among the noblest qualities of character.

Responsibility. Citizenship requires the pupil to be responsible for his companions, his class, and for the whole school. This feeling of responsibility is intrinsic to citizenship. Responsibility leads to making one's self the best possible example, by helping others in the best way. A sense of responsibility arouses manliness, self-confidence, and personal dignity. Education without responsibility is impossible.

TRUSTWORThiness. Trustworthiness is the outcome of responsibilty. Its main content is honesty. Its realization is through knowledge, skill, work, and faithfulness. Most of all, children like to be trusted. Suspicion of wrong-doing breeds wrong-doing. The students of Dr. Arnold said: "We never could tell him a lie, because he believed all we told him."

Helpfulness. Helpfulness comprehends nearly all of the other qualities of character. It demands study on the part of the helper of that which is most needed by others, for knowledge and skill are essential to efficient help. The art of teaching may be summed up in one purpose-the cultivation of the spirit of helpfulness.

TAste. Good taste, in a broad sense, comprehends a number of virtues. On one side is the love of the beautiful-taste in nature and art-admiration for the best painting, sculpture, literature, music, decoration, dress; discrimination between the beautiful and the ugly, between dirt and disorder, and cleanliness, neatness, and harmony. On the other side there are the recognition of truth, honesty, reason, and all the intrinsic virtues of noble character.

II. Intellect: Attention, OR ImaGing. Strong mental images, and images growing strong, form the basis of all intellectual growth. Images may be classified as follows:

I. Images that correspond to objects in the external world; acquired by observation.

2. Images of objects that lie beyond the sense grasp; acquired by hearing language, reading, pictures, maps.

3. Images formed by constructive and creative imagination.

The function of language, oral and printed, is to unite images that have already been in consciousness. If such images are strong, the new (united) image will be strong; if they are weak, the new image will be weak.

Analysis. Analysis of external objects depends entirely upon the images in consciousness; indeed, there can be no such thing as a growing image without analysis.

Comparison. Any two objects compared must have their corresponding images in consciousness. The value and thoroughness of the comparison depends upon the strength of the images.

Judgment and all the processes of reason have their foundation in strong images. 
Correlation. Correlation is the uniting or merging of congruous images. If images are strong, they move together into our apperceptive mass. This merging or growing of strong images is thoroughness.

Causal Relations. Strong images form the initial steps to the processes of reasoning which lead to a knowledge of causes. The images are the knowledge of the effects that may lead one to find the cause.

Persistence in Work. No mark of intellectual power is more promising than the habit of hard educational work under the right motive. Pupils who work out their own problems with little or no help, who overcome difficulties and stick to tasks that are not in themselves pleasant, who do the work assigned them, and far more, are on the road to successful lives. Teaching consists in inducing pupils to do excellent educative work.

Measuring Quantities (Arithmetic). Measuring quantities is intrinsic to all true study. Every branch of study demands constant measuring for the growth of clear images. The isolation of arithmetic in school work makes it difficult for teachers to use arithmetic properly.

Pure numbers require the learning and remembering of numerical facts. Measuring quantities demands imaging, analysis, comparison, and the exercise of reasoning power.

III. The Body: Defects of the body mean, in general, defects of the mind. No teacher can truly help a pupil without some knowledge of the bodily conditions named.

IV. Expression: Through expression in all its modes the teacher may read the characters of his pupils and understand their moral, mental, and physical strength and weakness. Each mode of expression reveals some phase of character. Expression has a powerful and indispensable reaction upon thought. Expression is essentially self-realization.

\title{
Colonial History
}

\author{
Emily J. Rice
}

The value of a history course in school depends very largely upon the relation it bears to the vital experiences of the children. If they are given an opportunity to do social work, they wish to know what they are doing, and why they are doing it. The first great mission of the school is to give the child something to do, and the second is to fill that work with meaning by showing its relation to the larger movements of life. It is more important that the material of the history lessons should have this close connection with the social activities of the school than that any logical order of the subject-matter should be considered. In fact, the kind of work being done suggests both historic subject and order of topics.

Experience has led us to believe that it is well to allow some one art especial prominence in each grade for the sake of carrying on the constructive work more thoroughly than would otherwise be possible. If the children are doing textile work, or making pottery, or learning to print or bind books, they may need a long time in which to secure a good result. When they are putting forth continued effort in a particular direction, study of the history of that activity shows the value of their labor in terms of the great field of human endeavor. This plan involves the 